\title{
KONTROVERSI JIDAT HITAM DI MADURA: Studi Penafsiran Komparatif-Sektarian QS. al-Fath [48]: 29
}

\author{
Mohammad Subhan Zamzami \\ Institut Agama Islam Negeri Madura, Indonesia \\ e-mail: mszamzami@stainpamekasan.ac.id
}

\begin{abstract}
This paper reveals athar al-sujüd's interpretation in QS. al-Fath [48]: 29 behind the controversy of the stigma of black foreheads against certain groups in Islam. This paper is a result of literature and fieldwork research based on comparative interpretation methods (tafsir muqārin) on five tafsìr books from different schools and interviews with some figures from different religious organizations in Madura. This research has discovered that the controversy from the stigma of a black forehead was not only triggered by different interpretations of athar al-sujüd in QS. al-Fath [48]: 29, but also by several hadiths narrated by Ahmad, al-Bayhaqī, and al-Bukhärī, which cause controversy among Muslims in Madura. In fact, no group in Islam wants such controversy, either as the subject of the accuser or the accused as a group of black foreheads.
\end{abstract}

\begin{abstract}
Abstrak: Artikel ini berusaha mengungkap penafsiran athar al-sujūd dalam QS. alFath [48]: 29 di balik kontroversi dari stigma jidat hitam terhadap kelompok tertentu dalam Islam. Artikel ini merupakan hasil penelitian studi literatur dan studi lapangan berdasarkan metode tafsir komparasi (tafsìr muqārin) terhadap lima kitab tafsir dari aliran berbeda dan wawancara dengan sebagian tokoh dari organisasi keagamaan berbeda di Madura. Penelitian ini berhasil mengungkap bahwa kontroversi dari stigma jidat hitam dipicu tidak hanya oleh perbedaan penafsiran atas athar al-sujūd dalam QS. al-Fath [48]: 29, tetapi juga dipicu oleh beberapa hadis riwayat Aḥmad, al-Bayhaqī, dan al-Bukhārī, sehingga menimbulkan kontroversi di kalangan umat Islam di Madura. Padahal sejatinya tidak ada satu kelompok pun dalam Islam yang menginginkan kontroversi ini, baik sebagai subjek penuduh maupun objek tertuduh sebagai kelompok jidat hitam.
\end{abstract}

Keywords: controversy; athar al-sujūd; blackforeheads; sectarian interpretation; Madura

\section{A. Pendahuluan}

Fenomena bekas hitam di dahi (jidat hitam) atau athar al-sujūd memunculkan pro dan kontra di tengah masyarakat di Indonesia, terutama di kalangan umat Islam. Ia tidak hanya termasuk dalam fenomena sosialkeagamaan, tetapi juga termasuk fenomena sosial-politik. Sebenarnya, feno- 
mena ini sudah ada sejak masa Islam awal, tetapi semakin mencuat ke permukaan seiring dengan munculnya beberapa fraksi umat Islam dalam konstelasi sosio-politik-keagamaan di Indonesia pascareformasi, yang sebelumnya tidak bisa mengungkapkan aspirasi politik-keagamaannya secara leluasa karena tekanan rezim Orde Baru. Setelah rezim Orde Baru tumbang dan Indonesia memasuki Era Reformasi, mereka semakin lantang mengungkapkan aspirasi politik-keagamaannya. ${ }^{1}$ Bahkan sebagiannya berhasil mendirikan partai politik yang masih bertahan hingga sekarang.

Meskipun berbeda organisasi, partai, dan mazhab, secara umum mereka memiliki kemiripan dalam pemikiran dasar tentang politik dan agama serta relasi antara keduanya, yaitu pemikiran dan aksi mereka yang formalistissimbolistis, ${ }^{2}$ bahkan sebagiannya fundamentalistis. Fraksi-fraksi ini bisa diklasifikasikan sebagai "kelompok jidat hitam" karena pelbagai faktor, yang di antaranya: pertama, sebagian tokoh dan pengikutnya berjidat hitam; dan kedua, mereka dianggap lebih mementingkan aspek lahiriah (formalistis-simbolistis) daripada aspek batiniah (substantif-esoteris) dalam persoalaan politik dan agama atau relasi antara keduanya. Tentu hal ini tidak menafikan fraksi umat Islam lainnya juga berjidat hitam, tetapi dua faktor utama itulah, terutama faktor kedua, yang membedakan mereka dari "kelompok jidat hitam" ini. Apalagi fenomena jidat hitam ini semakin menjadi trend seiring dengan menjamurnya kelompok tertentu di pelbagai kampus yang, menurut Ali Said Damanik, "menawarkan satu pandangan keagamaan yang fanatik serta seolah lebih saleh dan taat dibandingkan orang lain di sekitarnya."3

${ }^{1}$ Kajian lebih lengkap tentang pergeseran orientasi politik fraksi umat Islam ini pada masa Orde Baru dan Era Reformasi bisa baca: Idris Thaha, "Hubungan Islam dan Politik yang Mungkin di Indonesia," Studia Islamika 13, no. 2 (2006): 327-46, https://doi.org/10.15408/sdi.v13i2.572; Noorhaidi Hasan, "Multikulturalisme dan Tantangan Radikalisme," in Merayakan Kebebasan Beragama: Bunga Rampai 70 Tahun Djohan Effendi, ed. oleh Elza Peldi Taher (Jakarta: ICRP, 2009); Muhammad Harfin Zuhdi, "Fundamentalisme dan Upaya Deradikalisasi Pemahaman al-Qur'an dan Hadis," Religia 13, no. 1 (2010), https://doi.org/10.28918/religia.v13i1.176; Amin Mudzakkir, "Demokratisasi, Islamisasi, dan Posisi Kaum Minoritas: Pengalaman Indonesia (1)," Politik LIPI, 2012, http://www. politiklipi.go.id/kolom/kolom-1/politik-internasional/680-demokratisasi-islamisasi-dan-posisi-kaumminoritas-pengalaman-indonesia-1. Diakses pada tanggal 14 September 2017.

${ }^{2}$ Kelompok Islam simbolis-formalis memandang Islam sebagai agama sempurna yang mengatur semua aspek kehidupan, baik peribadatan, moral, sosial, ekonomi, maupun politik, sehingga mereka menyeru untuk kembali kepada al-Qur'an, sunah Nabi Muhammad saw. dan generasi Islam awal, dan meninggalkan sistem sosial, politik, dan ekonomi Barat. Baca: Zaprulkhan Zaprulkhan, "Relasi Agama dan Negara dalam Perspektif Islam," Walisongo: Jurnal Penelitian Sosial Keagamaan 22, no. 1 (2014): 105-32, https://doi.org/10.21580/ws.22.1.261.

${ }^{3}$ Abdurrahman Wahid, ed., Ilusi Negara Islam: Ekspansi Gerakan Islam Transnasional di Indonesia (Jakarta: LibForAll Foundation, 2009), 204. 
Penamaan atau klasifikasi "kelompok jidat hitam" masih bisa diperdebatkan, karena tiga asumsi utama: pertama, mereka berjidat hitam karena murni beribadah secara tekun, sehingga tanda hitam membekas pada dahi mereka akibat kelenturan kulit dahi dan mereka tanpa sengaja mendapatkannya bahkan tidak kuasa menolaknya; kedua, mereka berjidat hitam karena rajin beribadah dan ingin jidat mereka menghitam sebagai simbol ketekunan ibadah, sehingga mereka bangga dengan bekas hitam tersebut; dan ketiga, sebagian pihak menjadikan bekas hitam di dahi sebagai kritik bahkan celaan terhadap "kelompok jidat hitam" tersebut yang dianggap bertentangan dengan ajaran Islam. Tiga asumsi ini berdasarkan pada pengamatan sementara terhadap fenomena sosio-politik-keagamaan yang ada di tengah masyarakat, baik di dunia nyata maupun di dunia sosial media. ${ }^{4}$

Sebenarnya, semua kontroversi tersebut bermula dari perbedaan pemahaman dan penafsiran terhadap frasa athar al-sujüd dalam QS. al-Fath [48]: 29:

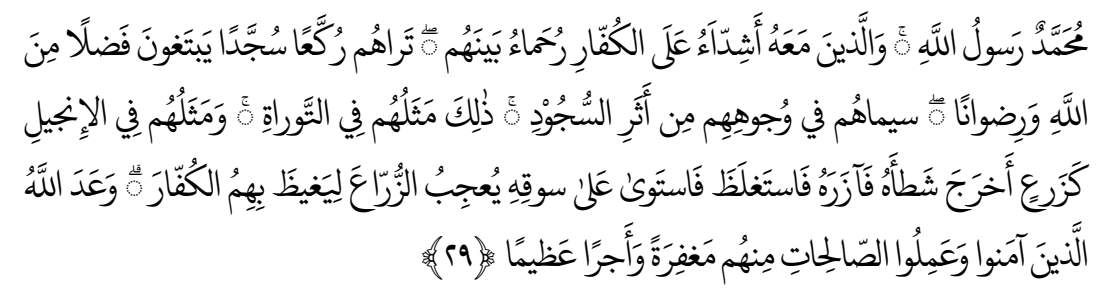

"Muhammad itu adalah utusan Allah dan orang-orang yang bersama dengannya adalah keras terhadap orang-orang kafir, tetapi berkasih sayang sesama mereka. Kamu lihat mereka sujud dan rukuk mencari karunia Allah dan keridaan-Nya, tanda-tanda mereka tampak pada muka mereka dari

\footnotetext{
${ }^{4}$ Analisis tentang jidat hitam dari sudut pandang sosial, agama, dan medis, terutama jidat hitam Freddy Budiman sebelum dieksekusi mati pada hari Jumat, 29 Juli 2016, di Pulau Nusakambangan, bisa baca: Reja Hidayat, "Dahi Hitam Freddy Budiman", dalam laman https://tirto.id/dahi-hitam-freddy-budiman-bx5a (Diakses pada tanggal 14 September 2017 pukul 13.38 WIB). Selain itu, kontroversi ini juga bisa dilacak dengan mudah di laman Youtube yang melibatkan penceramah dari lintas aliran atau organisasi keagamaan, seperti Firanda Andirja, Khalid Basalamah, Yazid bin Abdul Qadir Jawas, Maaher al-Thuwailibi, Badru Salam, Adi Hidayat, Habib Novel bin Muhammad Alaydrus, Abdul Somad, dan Buya Yahya.Video ceramah mereka bisa ditemukan dengan menggunakan kata kunci "jidat hitam", "dahi hitam", "bekas hitam di dahi", maupun "atsar al-sujud", seperti https://www.youtube.com/results?search_query=hitam+di+jidat, https://www.youtube.com/results?search_query=dahi+hitam, https://www.youtube.com/results? search_query=bekas+hitam+di+dahi, dan https://www.youtube.com/results?search_query=atsar +al-sujud (Diakses tanggal 08 Agustus 2018 pukul 12.20).
} 
bekas sujud. Demikianlah sifat-sifat mereka dalam Taurat dan sifat-sifat mereka dalam Injil, yaitu seperti tanaman yang mengeluarkan tunasnya maka tunas itu menjadikan tanaman itu kuat lalu menjadi besarlah ia dan tegak lurus di atas pokoknya; tanaman itu menyenangkan hati penanampenanamnya karena Allah hendak menjengkelkan hati orang-orang kafir (dengan kekuatan orang-orang mukmin). Allah menjanjikan kepada orangorang yang beriman dan mengerjakan amal yang saleh di antara mereka ampunan dan pahala yang besar."5

Dalam ayat ini, Allah menyebut "sìmāhum fi wujūhihim min athar al-sujūd" (tanda-tanda mereka tampak pada muka mereka dari bekas sujud) sebagai tanda bagi para pengikut setia Nabi Muhammad. Karena sebagian kosakata al-Qur'an mengandung banyak kemungkinan makna (dhū wujūh), ${ }^{6}$ maka pemahaman dan penafsiran terhadap ayat ini pun beragam. Apalagi kitab-kitab tafsir yang ada tidak sepenuhnya lepas dari latar belakang penafsirnya, baik latar belakang keilmuan maupun ideologinya. ${ }^{7}$ Dalam hal ini, 'Alī ibn Abū Ṭālib (w. 40 H./661 M.) berkata, "al-Qur'an hanyalah sebuah teks tertulis di antara dua sampul (mushaf). Ia tidak bisa berbicara, namun melaluinya manusia berwacana." 8

Dengan demikian, pemicu kontroversi jidat hitam pada mulanya adalah perbedaan pemahaman dan penafsiran atas QS. al-Fath [48]: 29, kemudian merambah pada polarisasi identitas sosial-keagamaan di tengah masyarakat. Namun apakah perbedaan pemahaman dan penafsiran ini didukung oleh penafsiran ulama lintas aliran keagamaan dalam kitab tafsir mereka, apakah sebenarnya makna frasa athar al-sujūd dalam QS. al-Fath [48]: 29, bagaimana pandangan tokoh dan anggota pelbagai organisasi keagamaan Islam (ormas) di Madura terhadapnya, dan apa dampaknya terhadap praktik sosial-keagamaan masyarakat Madura, inilah yang menjadi pertanyaan yang akan dipecahkan dalam penelitian ini.

${ }^{5}$ QS. al-Fath [48]: 29.

${ }^{6}$ Abdul Mustaqim, Paradigma Tafsir Feminis: Membaca al-Qur'an dengan Optik Perempuan (Yogyakarta: Logung Pustaka, 2008), 19.

${ }^{7}$ M. Subhan Zamzami, "Tafsir Ideologis dalam Khazanah Intelektual Islam," Mutawātir: Jurnal Keilmuan Tafsir Hadis 4, no. 1 (2014): 163-77, https://doi.org/10.15642/mutawatir.2014.4.1.163177.

${ }^{8}$ Mun'im Sirry, "Berlomba-lombalah dalam Kebaikan: Tafsir 5:48 dan Diskursus Kontemporer Pluralisme Agama," in Merayakan Kebebasan Beragama: Bunga Rampai 70 Tahun Djohan Effendi, ed. Elza Peldi Taher (Jakarta: ICRP, 2009), 146. 
Untuk menjawabnya, penelitian ini fokus pada lima kitab tafsir yang dianggap merepresentasikan pelbagai aliran dalam Islam, yaitu al-Kashshäf 'an Haqā̄iq Ghawāmiḍ al-Tanzīl wa 'Uyūn al-Aqāwīl fi Wujūh al-Ta'wīl karya Maḥmūd ibn 'Umar al-Zamakhsharī (467-538 H.)9 sebagai representasi kelompok Mu'tazilah ${ }^{10}$ atau Islam Rasional, Rūh al-Ma'ānī fi Tafsìr al-Qur'ān al-'Azìm wa al$S a b^{\prime}$ al-Mathānī karya Maḥmūd al-Alūsī al-Baghdādī (1217-1270 H.) ${ }^{11}$ sebagai representasi kelompok Sufi ${ }^{12}$ atau Islam Subtantif, Taysìr al-Karīm al-Raḥmān fi Tafsìr Kalām al-Mannān karya 'Abd al-Raḥman ibn Nāṣir al-Sa'dī (1307-1376 H./1887-1956 M. ${ }^{13}$ sebagai representasi kelompok Salafi-Wahabi, ${ }^{14}$ Fi Zilāl alQur'ān karya Sayyid Quṭub Ibrāhīm Ḥusayn Shādhilī (1906-1969 M.) ${ }^{15}$ sebagai representasi kelompok Tarbiyah atau Partai Keadilan Sejahtera (PKS) yang merupakan anak ideologis al-Ikhwān al-Muslimūn (IM), ${ }^{16}$ dan al-Mīzān fi Tafsìr alQur'ān karya Muhammad Ḥusayn al-Ṭabātabāî (1321-1410 H./1892-1981 M. ${ }^{17}$ sebagai representasi kelompok Syiah Imāmīyah. ${ }^{18}$

Selain itu, penelitian ini juga berdasarkan pada wawancara dengan para tokoh, pengurus, dan anggota organisasi keagamaan Islam (ormas) di setiap kabupaten di Madura, seperti Nahdlatul Ulama (NU), Muhammadiyah, Sarekat Islam (SI), dan Persatuan Islam (Persis), karena pandangan mereka dianggap cukup merepresentasikan pandangan para tokoh, pengurus, dan anggota yang lain secara umum. Sebagai data pelengkap, wawancara juga dilakukan dengan

9Jār Allāh Abū al-Qāsim Mahmūd ibn 'Umar al-Zamakhsharī, al-Kashshāf 'an Haqā’iq Ghawāmiḍ al-Tanzīl wa 'Uyūn al-Aqāwīl fí Wujūh al-Ta'wīl (Riyāḍ: Maktabah al-'Ubaykān, 1998). 322-327.

${ }^{10}$ Muhammad Ḥusayn al-Dhahabī, al-Tafsīr wa 'l-Mufassirūn (Kairo: Maktabah Wahbah, 2000),

${ }^{11}$ al-Alūsī al-Baghdādī, Rūh al-Ma'ānī fi Tafsìr al-Qur'ān al-'Azīim wa '-Sab' al-Mathānī (Beirut: Dār Ihyā̄' al-Turāth al-'Arabī, n.d.).

12al-Dhahabī, al-Tafsìr wa 'l-Mufassirūn, 256-7.

${ }^{13} \mathrm{Abd}$ al-Rahmōn ibn Nāṣir al-Saddī, Taysìr al-Karīm al-Rahmmān fí Tafsīr Kalām al-Mannān (Riyāḍ: Dār al-Salām, 2002).

${ }^{14}$ Izza Rohman, "Salafi Tafsirs: Textualist and Authoritarian?," Journal of Qur'an and Hadith Studies 1, no. 2 (2012): 197-213, https://doi.org/10.1548/QUHAS.V1I2.1324.

${ }^{15}$ Sayyid Quțub, Fị Zilāl al-Qur'ān (Kairo: Dār al-Shurūq, 2003).

${ }^{16}$ Akhmad Muawal Hasan, "Sayyid Qutb Mati, tapi Idenya Abadi bagi Kaum Islam-Politik," Tirto.id - Humaniora, 2017, https://tirto.id/sayyid-qutb-mati-tapi-idenya-abadi-bagi-kaum-islampolitik-cvvc.

${ }^{17}$ al-Sayyid Muhammad Ḥusayn al-Ṭabātabāīì, al-Mīzān fi Tafsìr al-Qur'ān (Beirut: Mu'assasah al-A'lamī li al-Maṭbū'àt, 1997).

18Khairunnas Jamal, "Pengaruh Pemikiran Husain Thabathaba'i dalam Tafsir al-Mishbah," Jurnal Ushuluddin 17, no. 2 (2011): 202-13, https://doi.org/10.24014/JUSH.V17I2.692. 
sebagian pengurus Majelis Ulama Indonesia (MUI) di Madura dan sebagian warga Madura yang berjidat hitam, karena mereka dianggap cukup merepresentasikan pandangan umat Islam yang lain di Madura yang berjidat hitam. Secara umum, pandangan mereka mewakili kelompok yang pro dan yang kontra dengan jidat hitam.

\section{B. Makna Athar al-Sujūd}

Frasa athar al-sujūd dalam QS. al-Fath [48]: 29 terdiri dari dua kata, yaitu athar dan sujūd yang tersusun dalam tarkīb iḍāfi. Kata pertama adalah kata athar. Ia merupakan kata benda bentuk tunggal yang berasal dari akar kata $a-t h-$ $r$ (أثر), yang bentuk jamaknya adalah āthār (آثار). Secara leksikal, menurut Ahmad ibn Fāris (w. 395 H.), athar bermakna "mendahulukan sesuatu" (taqdìm alshay'), "penyebutan sesuatu" (dhikr al-shay'), dan "tanda atau bekas sesuatu yang tersisa" (rasm al-shay' al-bāqì). ${ }^{19}$ Sedangkan menurut Ibn Manzūur (630-711 H./1232-1311 M.) athar bermakna "sisa sesuatu" (baqīyah al-shay'), "sisa dari bekas sesuatu" (mā baqiya min rasm al-shay'), dan "kabar" (khabar).20

Al-Qur'an menggunakan kata athar dan pelbagai kosakata lain yang berasal dari akar kata yang sama dengannya dalam jenis kata kerja (fi't), baik kata kerja aktif maupun pasif, dan jenis kata benda (ism), baik dalam bentuk tunggal maupun jamak, seperti athar, āthār, äthara, yu'tharu, tu'thiru, nu'thiru, yu'thiru, dan athärah. Varian kosakata ini disebutkan sebanyak 21 kali, yaitu dalam QS. alMudaththir [74]: 24, QS. al-Nāziāt [79]: 38, QS. Yūsuf [12]: 91, QS. al-Alā [87]: 16, QS. Țāhā [20]: 72, 83, dan 96, QS. al-Ḥashr [59]: 9, QS. al-Fath [48]: 29, QS. al-Rūm [30]: 50, QS. Ghāfir [40]: 21 dan 82, QS. al-Mā'idah [56]: 46, QS. al-Kahf [18]: 6 dan 64, QS. Yāsīn [36]: 12, QS. al-Ṣaffăt [37]: 70, QS. al-Zukhrūf [43]: 22 dan 23, QS. al-Ḥadīd [57]: 27, dan QS. al-Ahqāaf [46]: $4 .^{21}$

Dalam al-Qur'an, menurut al-Rāghib al-Aṣfahānī (w. 502 H./1108 M.), kata athar bermakna "hasil sesuatu yang menunjukkan keberadaannya" (husūl mā yadullu 'alā wujūdihi), seperti dalam QS. al-Ḥadīd [57]: 27, QS. Ghāfir [40]: 21,

\footnotetext{
${ }^{19} \mathrm{Abū}$ al-Husayn Aḥmad ibn Fāris ibn Zakarīyā, Mu'jam Maqāyīs al-Lughghah, 1 ed. (Beirut: Dār al-Fikr, 1979), 53.

20Ibn Manẓūr, Lisān al-'Arab (Beirut: Dār al-Fikr, 1386).

${ }^{21}$ Muhammad Fu'ād 'Abd al-Bāqī, al-Mu'jam al-Mufahras li Alfāẓ al-Qur'ān al-Karīm (Kairo: Dār al-Hadith, 1364), 11-2.
} 
dan QS. al-Rūm [30]: 50. Oleh karena itu, kata athar digunakan untuk jalan yang menunjukkan kepada orang-orang terdahulu, seperti dalam QS. al-Ṣaffāt [37]: 70 dan QS. Taha [20]: 83. Kata ma'äthir bermakna "sesuatu yang mengisahkan tentang kemuliaan-kemuliaan seseorang". Kata athar digunakan untuk kemuliaan, sedangkan kata ithār digunakan untuk pengutamaan, seperti dalam QS. alḤashr [59]: 9, QS. Yūsuf [12]: 91, dan QS. al-Alā [87]: 16.22

Kata kedua adalah kata sujūd. Ia merupakan kata benda yang berasal dari akar kata sin-jim-dāl (سجد). Secara leksikal, menurut Ibn Fāris, kata sajada bermakna "ketenteraman" (tațāmun) dan "ketundukan" (dhull). ${ }^{23}$ Menurut Ibn Sīdah (1007-1066 M.), sebagaimana dikutip oleh Ibn Manzūur, kata sajadayasjudu-sujūd bermakna "meletakkan dahi di atas tanah" (waḍa'a jabhatahu bi al-arḍ), sedangkan menurut Abū Bakr bermakna "membungkukkan diri dan menenteramkan diri di atas tanah" (inḥanā wa tațāmana ilā al-arộ). Ia juga bermakna "tunduk" (khada'a). Sujud dalam salat yaitu meletakkan dahi di atas tanah. Sujud ini merupakan sujud yang paling mulia.24

Al-Qur'an menggunakan kata sujūd dan pelbagai kosakata lain yang berasal dari akar kata yang sama dengannya dalam jenis kata kerja ( $\left.f^{\prime} t\right)$ dan jenis kata benda (ism), seperti sajada, sajadū, asjudu, tasjudu, tasjudū, nasjudu, yasjudāni, yasjudū, yasjudūna, usjud, usjudū, usjudī, sujūd, sājid, sājidūna, sājidīna, sujjad, masjid, dan masājid, yaitu dalam QS. al-Hijr [15]: 29, 30, 31, dan 33, QS. Șād [38]: 73 dan 75, QS. al-Baqarah [2]: 34, QS. al-Nisā' [4]: 102, QS. al-A'rāf [7]: 11, 12, 120, dan 206, QS. al-Isrā' [17]: 61, QS. al-Kahf [18]: 50, QS. Țaha [20]: 116, QS. Fușșilat [41]: 37, QS. al-Furqān [25]: 60, QS. al-Ra'd [13]: 15, QS. al-Naḥl [16]: 49, QS. al-Hajj [22]: 18 dan 77, QS. al-Rahmmān [55]: 6, QS. al-Naml [27]: 24 dan 25, QS. Āl 'Imrān [3]: 3 dan 113, QS. al-Inshiqāq [84]: 21, QS. al-Insān [76]: 26, QS. al'Alaq [96]: 19, QS. al-Najm [53]: 62, QS. al-Fatḥ [48]: 29, QS. Qāf [50]: 40, QS. alQalam [68]: 42 dan 43, QS. al-Zumar [39]: 9, QS. al-Tawbah [9]: 112, dan QS. Yūsuf [12]: 4.25

\footnotetext{
22al-Rāghib al-Aṣfahānī, Mufradāt Alfāza al-Qur'ān (Damaskus: Dār al-Qalam, 2009), 62.

23Zakarīyā, Mu'jam Maqāyiss al-Lughghah, 133.

24Manẓūr, Lisān al-'Arab, 1940-1941.

25al-Bāqī, al-Mujam al-Mufahras,344-345.
} 
Menurut Ismāīl ibn Aḥmad al-Ḥayrī (361-431H.), kata sujūd dalam alQur'an memiliki enam makna. Pertama, ia bermakna "sujud syukur", yaitu dalam QS. al-Baqarah [2]: 34, QS. al-Hiijr [15]: 30 dan 98, dan QS. Șād [38]: 73. Kedua, ia bermakna "orang-orang yang salat", yaitu dalam QS. al-'Alaq [96]: 19, QS. al-Baqarah [2]: 125, QS. al-Ḥajj [22]: 26, QS. Āli 'Imrān [3]: 43 dan 113, QS. alDahr/al-Insān [76]: 26, QS. Qāf [50]: 40, QS. al-Ḥijr [15]: 98, dan QS. al-Shu'arā' [26]: 219. Ketiga, ia bermakna "sujud", yaitu dalam QS. al-Hajj [22]: 77 dan QS. al'Alaq [96]: 19. Keempat, ia bermakna "penundukan", yaitu dalam QS. al-Naḥl [16]: 48 dan QS. al-Raḥmān [55]: 6. Kelima, ia bermakna "tawaduk", yaitu dalam QS. Yūsuf [12]: 100. Keenam, ia bermakna "khusyuk", yaitu dalam QS. al-Furqān [25]: $60 .{ }^{26}$

Berdasarkan makna leksikal dan penggunaannya dalam al-Qur'an, kata athar mengandung makna "bekas, tanda atau sisa sesuatu yang bersifat mulia", sedangkan kata sujūd mengandung makna "sikap tunduk, tawaduk, dan khusyuk yang bersifat keagamaan dan bisa menenteramkan diri". Jadi frasa athar al-sujüd dalam QS. al-Fath [48]: 29 identik dengan bekas atau tanda kemuliaan berupa ketundukan, ketawadukan, dan kekhusyukan yang terkait dengan ritual keagamaan dan menenteramkan hati. Meskipun demikian, sebagian kelompok umat Islam menafsirkan frasa ini secara konkret (hissī) berupa tanda hitam di dahi sehingga menganggapnya sebagai tanda kesalehan seorang Muslim, sedangkan kelompok lain tetap menafsirkannya secara abstrak (ma'nawi ${ }^{27}$ berupa sikap tunduk, tawaduk, khusyuk, dan ketenteraman hati sehingga menyalahkan orang yang berjidat hitam bahkan menuduhnya melakukan riyā'. Untuk menguji keabsahan penafsiran dua kelompok yang sebagiannya lebih disebabkan oleh sektarianisme,28 maka pelacakan secara

${ }^{26} \mathrm{Abū}$ 'Abd al-Raḥmān Ismāīl ibn Ahmad al-Hayrī al-Naysābūrī, Wujūh al-Qur'ān (Masyhad: Majma' al-Buhūth al-Islā̉mìyah, 1422), 299-300.

${ }^{27}$ Artikel ini menggunakan istilah "penafsiran konkret" (tafsìr hissī) dan penafsiran abstrak (tafsïr ma'nawi) untuk menggambarkan pemahaman dan penafsiran ulama dan para informan atas Qs. al-Fath [48]: 29. Penafsiran konkret (tafsir hissī) yang dimaksud dalam artikel ini adalah penafsiran yang cenderung pada konsekuensi fisik terkait dengan frasa athar al-sujüd, sedangkan penafsiran abstrak (tafsìr ma'nawi) adalah penafsiran yang cenderung pada konsekuensi non-fisik terkait dengan frasa athar al-sujūd.

${ }^{28}$ Sektarianisme adalah semangat membela suatu sekte atau mazhab, kepercayaan, atau pandangan agama yang berbeda dari pandangan agama yang lebih lazim diterima oleh para penganut agama tersebut. Tim Redaksi Pusat Bahasa, Kamus Besar Bahasa Indonesia Uakarta: Gramedia Pustaka Utama, 2013), 1245. 
kronologis terhadap penafsiran lima ulama tafsir yang berbeda aliran di atas tentang frasa athar al-sujüd penting dilakukan.

\section{Athar al-Sujūd dalam Penafsiran Sektarian}

Penafsiran sektarian diungkapkan secara berbeda oleh para sarjana. Ignác Goldziher (1850-1921 M.), misalnya, mendefinisikannya sebagai usaha umat Islam mencari legitimasi terhadap ideologi dan mazhabnya dari al-Qur'an. Ḥasan Ḥanafì menyebutnya sebagai penafsiran dogmatis, sedangkan Naṣr Ḥāmid Abū Zayd (1943-2010 M.) menyebutnya sebagai penafsiran talwīn yaitu pemberian warna atas teks sesuai dengan pemahaman awal. Meskipun demikian, semua definisi mereka sama-sama mengacu pada sistem interpretasi yang berusaha melegitimasi ideologi dan kelompok sang penafsir. ${ }^{29}$

Al-Kashshäf karya al-Zamakhsharī merupakan salah satu contoh terbaik penafsiran sektarian. Al-Zamakhsharī merupakan seorang imam besar Mu'tazilah yang ahli tafsir, hadis, nahwu, bahasa, dan sastra, sehingga penafsirannya bias Mu'tazilah. ${ }^{30}$ Dalam pandangannya, secara leksikal, kata simah dalam QS. alFath [48]: 29 bermakna "tanda" ('alāmah), yaitu tanda di dahi para ahli sujud karena sering sujud, sehingga makna "min athar al-sujüd adalah pengaruh yang diakibatkan oleh sujud. Dalam hal ini, dia mengafirmasi keabsahan dua macam penafsiran terhadap athar al-sujūd, yaitu penafsiran abstrak (mánawi) berupa warna kekuning-kuningan dan cahaya pada wajahkarena taat beribadah dan penafsiran konkret (hissī) berupa tanda hitam pada wajah seperti thafinah albaîr (bagian tubuh unta yang menempel tanah saat menderum). ${ }^{31}$

Sebagai legitimasi atas keabsahandua macam penafsiran ini,dia mengutip pendapat sebagian tabiin seperti al-Ḍaḥhāk, Sa'îd ibn al-Musayyab, dan 'Ațā' untuk penafsiran yang abstrak. Dalam hal ini, Ațā' melandaskan penafsirannya pada hadis "man kathurat șalātuhu fi al-layl hasuna wajhuhu fi al-nahär" (barang siapa yang sering salat pada malam hari, niscaya wajahnya akan tampak bagus pada siang harinya). Sedangkan untuk penafsiran yang konkret, dia menunjukkan data historis berupa dua orang saleh yang dijuluki sebagai $d h u \bar{u} a l-$

\footnotetext{
${ }^{29}$ Mawardi Mawardi, "Subjektivitas dalam Penafsiran Al-Quran: Fenomena Tafsir Bercorak Sektarian," At-Tibyan: Jurnal Ilmu al-Qur'an dan Tafsir 3, no. 1 (2018): 125-38, https://doi.org/ 10.32505/tibyan.v3i1.483.

30al-Dhahabī, al-Tafsìr wa al-Mufassirūn, 304-313.

${ }^{31}$ al-Zamakhsharī, al-Kashshāf, 551-553.
}

JURNAL THEOLOGIA — Volume 29, Nomor 2, Desember 2018 
thafināt yaitu 'Alī ibn al-Ḥusayn Zayn al-'Ābidīn dan 'Alī ibn 'Abd Allāh ibn 'Abbās Abū al-Amlāk, yang memiliki bekas hitam di dahi karena sering sujud. Meskipun demikian, dia menekankan tanda hitam pada wajah tersebut karena ikhlas beribadah, bukan karena kesengajaan yang disebabkan olehnifak dan riyā', sehingga tidak termasuk dalam larangan merusak wajah sebagaimana athar dari 'Umar ibn al-Khattāăb. ${ }^{32}$

Selang tujuh abad berikutnya, makna leksikal athar dan dua macam penafsiran ini juga diungkapkan oleh al-Alūsī, seorang mahaguru ulama di Irak yang ahli tafsir, hadis, fikih, dan teologi dari mazhab al-Shāfíi, ${ }^{33}$ dalam kitab tafsirnya yang bercorak sufistik, Rūh al-Ma'ānī. Selain itu, dia menukil empat riwayat dari sahabat dan tabiin yang berbeda-beda terkait penafsiran sebagian kata dalam QS. al-Fath [48]: 29, yang ditafsirkan dengan nama-nama sahabat Nabi. Ayat sīmāhum fi wujūhim min athar al-sujūd, misalnya, ditafsirkan sebagai 'Abd al-Raḥmān ibn 'Awf, Sa'd ibn Abū Waqqāṣ, dan Abū 'Ubaydah ibn al-Jarrāḥ. Namun, menurut al-Alūsī, empat riwayat ini tidak sahih. Sebaliknya, dia menafsirkan athar al-sujūd sebagai bekas sujud kepada Allah, bukan sujud kepada sesuatu dari urusan duniawi dan akhirat, yang merupakan tanda orangorang yang bersama Nabi. Tanda ini berupa anugerah cahaya-cahaya ketuhanan (khal' al-anwār al-ilāhīyah). ${ }^{34}$

Berbeda dengan al-Zamakhsharī dan al-Alūsī, al-Sa'dī hanya mengafirmasi penafsiran abstrak atas frasa athar al-sujūd dalam Taysīr al-Karīm al-Raḥmān. Padahal dia merupakan ahli fikih, usul fikih, dan tafsir yang merupakan murid dari Muḥammad al-Amīn al-Shinqīịi (1907-1973 M.) dan guru dari Muḥammad ibn Șālih al-'Uthaymin (1925-2001), ${ }^{35}$ tokoh kelompok Salafi-Wahabi, dan kitab tafsirnya merupakan kitab tafsir rujukan kelompok ini yang identik dengan penafsiran dan pemahaman ahistoris-tekstual dalam beragama. ${ }^{36}$ Menurut alSa'dī, athar al-sujūd adalah sinar pada wajah sebagai bekas ketekunan ibadah, yang pada awalnya menyelimuti batin orang yang tekun beribadah lantas

\footnotetext{
32al-Zamakhsharī.

${ }^{33}$ al-Dhahabī, al-Tafsìr wa al-Mufassirūn, 250-251.

34al-Baghdādī, Rūḥ al-Ma'ānī, Vol. 26: 123-131.

${ }^{35} \mathrm{Abū}$ al-Ashbāl Ahmad ibn Sālim al-Miṣrī, Shadharāt al-Balātīn min Siyar al-Ulamā' alMu'âșirīn (Riyaụ: Dār al-Kayān, 2006), 100-4.

${ }^{36}$ Rohman, “Salafi Tafsirs: Textualist and Authoritarian?” 197-198.
} 
menyelimuti zahir mereka. Dia menafsirkan ayat ini dalam konteks sahabat Nabi, baik sahabat senior maupun sahabat yunior, terutama yang terlibat dalam perjanjian Hudaibiah. ${ }^{37}$

Sayyid Quțub menyebut para sahabat yang terlibat dalam perjanjian Hudaibiah tersebut sebagai al-majmü'ah al-farïdah al-sa'îdah dalam Fì Zilāl alQur'ān. Secara substantif, penafsiran al-Sa'dī atas athar al-sujüd sama dengan penafsiran Quțub yang hanya mengafirmasi penafsiran abstrak, tetapi Quțub secara vulgar menolak penafsiran konkret atas frasa ini. Dalam pandangan ideolog al-Ikhwān al-Muslimūn (IM) ini, athar al-sujūd adalah bekas ibadah (athar al-ibādah), yaitu tanda pada wajah yang bersih (waḍā'ah), bercahaya (ihsrāq), jernih (șafā), dan bening (shafäfiyah) karena tekun beribadah sebagai tanda kekhusyukan, ketundukan, dan ibadah kepada Allah yang paling sempurna, yang menghilangkan sikap angkuh, sombong, dan merasa pintar. Sebaliknya, dia menegasikannya sebagai tanda hitam (nuktah) pada wajah sebagaimana lazim dipersepsikan. ${ }^{38}$

Berbeda dengan al-Zamakhsharī, al-Alūsī, al-Sa'dī, dan Quțub yang secara eksplisit mengaitkan ayat ini dengan para sahabat Nabi, al-Ṭabāțabāî tidak secara eksplisit mengaitkannya dengan mereka dalam al-Mìzān. Menurutnya, makna kata simā adalah tanda ('alāmah), yaitu sujud kepada Allah dengan merendahkan diri dan khusyuk, sehingga membekas pada wajah berupa tanda kekhusyukan kepada Allah yang terlihat oleh orang yang memandangnya. Sebagai tokoh Syiah, dia mengutip pendapat al-Ṣadiq bahwa tanda itu terkait dengan melek malam untuk salat sebagai legitimasi atas penafsirannya. Selain itu, dia mengutip pendapat lain bahwa makna athar al-sujūd adalah: (a) bekas debu di dahi, karena salat di atas debu bukan di atas kain; dan (b) tanda pada hari kiamat berupa cahaya terang pada tempat sujud. 39

Secara teoretis, uraian tentang penafsiran lima ulama tafsir yang berbeda aliran keagamaan di atas membatalkan persepsi sebagian pihak bahwa athar alsujūd lebih identik dengan kelompok tertentu dalam Islam yang formalissimbolis dalam beragama dan bernegara, seperti Salafi-Wahabi dan al-Ikhwān al-Muslimūn (IM) serta kelompok lain yang berafiliasi pada keduanya, karena

\footnotetext{
${ }^{37}$ al-Sa'dī, Taysìr, 938-939.

${ }^{38}$ Quțub, Fì Zilāl al-Qur'ān, 3324-3333.

${ }^{39}$ al-Ṭabāțabāî̀, al-Mīzān fi Tafsìr al-Qur'ān, Juz 18, 3002-4.
} 
Taysīr al-Karīm al-Raḥmān dan Fì Zilāl al-Qurāan yang merupakan referensi utamanya justeru hanya mengafirmasi penafsiran abstrak atas athar al-sujūd. Bahkan, sebaliknya, penafsiran konkretnya diafirmasi dalam al-Kashshāf, Rūh alMa'ānī, dan al-Mīzān yang merupakan referensi kelompok yang nyaris tidak tersentuh oleh stigma sebagai "kelompok jidat hitam". Untuk mendapatkan gambaran lebih utuh tentang stigma ini pada tataran teoretis dan tataran praksis di Madura, elaborasi tentang persepsi sebagian tokoh lintas organisasi keagamaan dan pemilik jidat hitam di Madura penting untuk dilakukan.

\section{Athar al-Sujūd dalam Pandangan Masyarakat}

Pandangan mereka tentang stigma ini mengacu pada lima persoalan utama, yaitu: 1) makna "sīmāhum fi wujūhihim min athar al-sujūd" dalam QS. al-Fath [48]: 29; 2) athar al-sujüd sebagai tanda kesalehan seorang muslim atau bukan; 3) ada atau ketiadaan bekas hitam pada dahi Nabi Muhammad saw. dan sahabatnya; 4) persepsi tentang seorang muslim yang berjidat hitam; dan 5) persepsi masyarakat setempat tentang seorang muslim yang berjidat hitam.

Berdasarkan bacaannya atas tafsir al-Ṭabarī dan pengamatannya atas fenomena jidat hitam, Ayyub Mustofa mengakui athar al-sujüd merupakan tanda kesalehan seorang muslim yang bersifat abstrak, tetapi bukan secara mutlak berupa bekas hitam di dahi, karena naif mengaitkan bekas ini dengan intensitas ibadah seseorang. "Athar al-sujūd adalah tanda kesalehan seorang muslim. Mengenai bekas hitam di dahi memang ada beberapa yang menyebutkan demikian, tetapi tidaklah mutlak penyebabnya adalah intensitas ibadah yang dilakukan. Beberapa ulama tafsir, misalnya al-Ṭabarī, mengatakan tanda itu akan terlihat nanti di hari kiamat yang digambarkan dengan mencorongnya wajah ahli sujud," tukas Wakil Ketua GP. Ansor Nahdlatul Ulama (NU) Bangkalan ini. ${ }^{40}$

Secara substansi, penuturan Mustofa seirima dengan penuturan Nur Laili. Dengan mengutip ulama tafsir, hadis riwayat al-Ṭabrānī, dan pendapat Mujāhid, pengurus Fatayat Nahdlatul Ulama Bangkalan ini lebih setuju athar al-sujūd ditafsirkan secara abstrak berupa simt hasan, khushū', dan tawādu' di dunia sedangkan di akhirat berupa cahaya putih. Sebaliknya, dia menafikan tanda ini berupa tanda hitam di dahi. Bahkan, sebagai legitimasinya,dia mengutip riwayat

\footnotetext{
40Ayyub Mustofa, Wawancara, tanggal 15 Mei 2018.
} 
al-Ṭabrānī yang mengisahkan tatkala Sa'îd ibn Yazīd melihat bekas sujud pada wajah Zubayr ibn Suhayl ibn 'Abd al-Rahmān ibn 'Awf, Sa'îd berkata, "Orang ini telah merusak wajahnya. Ingat, demi Allah, bukan inilah tanda ahli sujud yang dimaksud oleh Allah! Sungguh aku telah bersujud selama 80 tahun, tetapi tidak sedikit pun ia membekas di antara kedua mataku." Apalagi hingga saat ini Laili belum menemukan bukti Nabi dan sahabatnya memiliki bekas hitam di dahi mereka karena rajin beribadah. 41

Selain dalam literatur tafsir, persoalan athar al-sujūd memang juga ditemukan dalam literatur hadis. Al-Bayhaqi (w. 458 H.), misalnya, dalam al-Sunan al-Kubrā meriwayatkan enam hadis pada subbab Simāhum fi Wujuhihim min Athar al-Sujūd yang semuanya lebih mengarah pada penafsiran abstrak atas athar al-sujüd dan mencela adanya bekas konkret pada wajah.42 Meskipun berbeda organisasi keagamaan dengan Mustofa dan Laili di kota yang sama, Donny Burhan pun lebih cenderung pada penafsiran abstrak atas athar al-sujūd berupa aura wajah yang cerah dan cermin perbuatan baik dari perbuatannya sebagai tanda kesalehan. Meskipun demikian, pengurus Pimpinan Daerah Muhammadiyah Bangkalan ini tidak menafikan adanya penafsiran konkret berupa simbol hitam di dahi, tetapi penafsiran ini relatif karena kulit sebagian orang mengalami kelainan. ${ }^{43}$

Pendapat lebih lugas dituturkan oleh Ketua Sarekat Islam (SI) Sampang, Nurul Hadi. Dalam pandangannya, QS. al-Fath [48]: 29 menunjukkan bahwa orang saleh yang sering bersujud kepada Allah akan terpancar tanda-tanda seperti berseri-seri, cerah bercahaya, dan tidak gelisah dari raut mukanya. Oleh karena itu, meskipun berjidat hitam, dia jujur mengakui adanya kesan kekurangikhlasan ibadah orang yang berjidat hitam, yang bisa berupa hitam pekat, samarsamar, dan sekadar berbekas. Apalagi hingga kini dia tidak mengetahui Nabi dan sahabatnya memiliki bekas hitam itu. ${ }^{4}$ Sesama warga Sampang yang berjidat hitam, Arifin lebih bijak. Dia memandang orang yang ahli ibadah tidak harus berjidat hitam. Sebaliknya, orang yang berjidat hitam tidak seharusnya diolok-

${ }^{41}$ Nur Laili, Wawancara, tanggal 15 Mei 2018.

${ }^{42} \mathrm{Abū}$ Bakr Ahmad ibn al-Ḥusayn ibn 'Alī Al-Bayhaqī, al-Sunan al-Kubrā, Juz 2 (Beirut: Dār alKutub al-'Ilmìyah, 2003), 406-7.

${ }^{43}$ Donny Burhan, Wawancara, tanggal 15 Mei 2018.

${ }^{44}$ Nurul Hadi, Wawancara, tanggal 03 Mei 2018. 
olok. Setidaknya, kita bisa menghargai ketekunannya dalam beribadah dan melihat akhlaknya. Apalagi masyarakat di sekitarnya menggapnya sebagai orang yang sering Tahajud. 45

Orang yang berjidat hitam tidak hanya dipersepsikan sebagai orang yang sering salat Tahajud sebagaimana terjadi pada warga Sampang bagian utara tempat Arifin tinggal, tetapi dia juga dipersepsikan sebagai orang saleh, ahli ibadah, dan dekat dengan Allah sebagaimana terjadi pada warga Sampang bagian selatan tempat Azhar Amrullah Hafiz tinggal. Laki-laki yang juga berjidat hitam ini berasal dari keluarga campuran Nahdlatul Ulama dan Muhammadiyah. Meskipun mengakui kemungkinan sebagian sahabat memiliki bekas hitam di dahi sebagaimana tampak dalam sanggahan Ibn 'Abbās, dia cenderung memilih penafsiran abstrak atas athar al-sujüd dengan alasan kalau athar al-sujüd memang bekas hitam di dahi maka redaksi ayat seharusnya "simāhum fi jibāhihim" bukan "sīmāhum fi wujūhihim". ${ }^{4}$

Penolakan mentah-mentah terhadap penafsiran konkret atas athar al-sujūd dilontarkan oleh Abdul Ghanie, Wakil Ketua Lakpesdam Nahdlatul Ulama Pamekasan. Menurutnya, athar al-sujüd adalah cahaya pada wajah sebagai output ibadah, bukan bekas hitam di dahi, karena kesalehan seseorang tidak ditentukan oleh tanda itu. Bahkan tanda tidak baik, karena orang yang berjidat hitam cenderung pamer yang seakan berkata, "Ini Iho saya ahli ibadah. Buktinya, jidat hitam." 47 Tanda hitam ini, menurut Abdul Mukti Thabrani, muncul karena sering sujud secara emosional, karena athar al-sujūd bukan tanda fisik dan bukan tanda kesalehan. Tanda kesalehan adalah akhlak, yang di antaranya wajah yang teduh, menyenangkan, basātah, dan ceria sebagai ekspresi dari $l \bar{a}$ khawf'alayhim wa lā hum yạ̣zanūn, karena sujud yang intens. Pengurus Sarekat Islam (SI) Pamekasan ini memastikan Nabi dan para sahabatnya tidak memiliki tanda hitam di dahi walau sering salat. Seandainya ada, pasti disebut dalam hadis. Paling tidak dalam sifat fisik Nabi. Begitu juga para sahabatnya. 48

Pernyataan Thabrani diamini oleh Ketua Majelis Tarjih Muhammadiyah Pamekasan, Ibnu Kusuma Negara. Dengan mengutip al-Tafsir al-Wasit karya al-

\footnotetext{
${ }^{45}$ Arifin, Wawancara, tanggal 13 Mei 2018.

46Azhar Amrullah Hafiz, Wawancara, tanggal 18 Mei 2018.

${ }^{47}$ Abdul Ghanie, Wawancara, tanggal 16 Mei 2018.

${ }^{48}$ Abdul Mukti Thabrani, Wawancara, tanggal 26 April 2018.
} 
Sayyid al-Ṭantāwī, dia menjelaskan tanda itu berupa cahaya dan ketenteraman pada wajah orang yang sering beribadah. Dia pun menegaskan Nabi dan para sahabatnya tidak memiliki bekas hitam di dahi mereka. Meskipun demikian, siapa pun yang melihat beliau, niscaya akan merasa tenteram. Karena sebagian orang yang berjidat hitam memang sengaja menggosokkan dahinya agar hitam, maka untuk menetapkan seorang sebagai ahli ibadah harus dilihat dari akhlaknya. ${ }^{49}$ Abdus Syukur menimpali pernyataan Kusuma Negara. Menurut anggota Majelis Tarjih Muhammadiyah Pamekasan yang berjidat hitam ini, jika sujudnya benar maka dia orang saleh, tetapi jika tidak maka banyak sujud tidak akan berpengaruh. .50

Kemungkinan seperti ini memang diakui oleh Muhammad Abdul Kuddus. Sebagai orang yang berjidat hitam, anggota Majelis Ulama Indonesia (MUI) Pamekasan ini menjelaskan tiga kemungkinan bekas hitam tersebut, yaitu: 1) dia memang rajin sujud; 2) dia melakukan kesalahan dalam bersujud; dan 3) dia termasuk orag yang mudah kapalan. Apalagi selain lebih cenderung pada penafsiran abstrak atas athar al-sujüd sebagaimana pernyataan Kusuma Negara dan Syukur, dia juga belum menemukan keterangan bahwa Nabi dan para sahabatnya memiliki bekas hitam di dahi. ${ }^{51}$

Kapalan akibat sensitivitas kulit ini dipertegas oleh Ahmad Syaukani, simpatisan Persatuan Islam (Persis). Menurutnya, sensitivitas kulit setiap orang berbeda, sehingga bekas di dahi bukan jaminan kesalehan seseorang apalagi tidak bisa dipastikan hal itu muncul karena keinginannya, karena athar al-sujūd adalah good attitude, good behavior, dan good value, meskipun sebagian orang memersepsikan tanda hitam di dahi adalah athar al-sujūd.52

Semua informan memang menafikan bekas hitam di dahi sebagai tanda kesalehan, karena menurut Moh. Anwar tidak semua orang saleh (harus) punya tanda itu. Pengurus Sarekat Islam (SI) Sumenep ini menjelaskan bahwa Allah tidak memandang orang dari penampilan lahirnya, apalagi tidak ada dalil tentang itu, karena athar al-sujūd adalah tanda (cahaya) di akhirat kelak. ${ }^{53}$

\footnotetext{
49Ibnu Kusuma Negara, Wawancara, tanggal 27 April 2018.

50Abdus Syukur, Wawancara, tanggal 14 Mei 2018.

51Muhammad Abdul Kuddus, Wawancara, tanggal 26 April 2018.

${ }^{52}$ Ahmad Syaukani, Wawancara, tanggal 26 Mei 2018.

${ }^{53}$ Moh. Anwar, Wawancara, tanggal 14 Mei 2018.
} 
Afifullah, anggota Majelis Ulama Indonesia (MUI) Bluto Sumenep, menambahkan bahwa implikasi dari bekas salat adalah amal, sehingga makna athar alsujūd bukan makna zahir berupa bekas hitam di dahi. ${ }^{54}$ Dibanding semua informan lain, keterangan Zainur Rahman lebih detail sehingga dianggap mewakili semua keterangan para informan sebelumnya. Bahkan dia menyebut kelompok Salafi-Wahabi terkait dengan kontroversi jidat hitam ini. Berikut penuturan pengurus Nahdlatul Ulama (NU) Sumenep tersebut:

"Dari berbagai penafsiran yang saya temukan, makna athar al-sujūd dalam QS. al-Fath [48]: 29 merujuk pada satu dari dua hal: (1) wajah yang bercahaya kelak di hari kiamat; atau (2) perilaku yang baik dan hati yang khusyuk sebagai efek (athar) salatnya. Jika berdasar pengertian athar alsujūd tersebut, maka ia menjadi indikator kesalehan seorang muslim, karena orang tersebut bisa dikatakan orang yang al-qāim bi ḥuqūq Allāh wa bi ḥuqūq ibādihi (sebagai definisi al-șālih). Saya belum menemukan satu pun riwayat yang mengatakan Nabi Muhammad saw. dan sahabatnya memiliki bekas hitam di dahi mereka karena rajin ibadah. Yang saya temukan malah riwayat yang menegaskan bahwa kanjeng Nabi șallā Allāh 'alayhi wa sallama dan beberapa sahabat utama radilya Allāh 'anhum tidak memiliki tanda hitam di dahi. Lalu ada beberapa riwayat lain yang mengindikasikan bahwa sebaiknya tidak pernah ada kapalan bekas sujud di dahi kita. Yang saya tahu, ada tipe jidat yang kulitnya memang tipis, sehingga mudah mengapal karena disujudkan. Apalagi jika alas sujudnya kasar. Jadi kalau ada jidat seseorang begitu, anggap saja dia memiliki kulit dahi yang tipis. Dulu, di masa kecil-remaja, yang saya tahu, sebagian orang menganggap jidat hitam menandakan pemiliknya rajin Tahajud. Belakangan, selain ada yang menganggap pemilik jidat hitam itu orang yang rajin Tahajud, ada juga yang langsung 'mencurigai' pemilik jidat hitam sebagai penganut paham Salafi/Wahabi. Tapi, jangan lupa, masih ada kemungkinan lain; bukan rajin Tahajud, bukan Salafi/Wahabi, tetapi semata karena kulit jidatnya emang tipis dan sensitif." 55

\section{E. Athar al-Sujūd sebagai Identitas Sosial-Keagamaan}

Semua penafsiran, baik penafsiran abstrak maupun penafsiran konkret atas athar al-sujüd, dalam lima literatur tafsir dan komentar para tokoh atau simpatisan organisasi keagamaan dan pemilik jidat hitam di atas sejatinya

${ }^{54}$ Afifullah, Wawancara, tanggal 19 Mei 2019.

55Zainur Rahman, Wawancara, tanggal 14 Mei 2018. 
terkait dengan identitas seseorang. Setiap orang memiliki dua identitas, yaitu: (a) identitas personal (personal identity) berdasarkan identifikasi diri, baik oleh diri sendiri maupun orang lain, berupa ciri fisik dan psikologis; dan(b) identitas sosial (social identity) berdasarkan identifikasi diri oleh orang lain kepada seseorang sebagai aktor sosial (social actor), berupa agama, etnis, dan kelas sosial. ${ }^{56}$ Sebagian pihak menggunakan identifikasi ini dalam proses perbandingan sosial untuk menentukan ingroup dan outgroup, baik dengan nonMuslim maupun sesama Muslim, berdasarkan penafsiran abstrak dan penafsiran konkret atas athar al-sujüd.

Khusus penafsiran konkretnya berupa tanda hitam di dahi, misalnya, hanya identik dengan umat Islam, karena tanda ini tidak ditemukan pada fisik pemeluk agama lain. Sedangkan pada sesama Muslim, ia identik dengan kelompok tertentu dalam Islam. Poin terakhir ini memang tidak ada dalam lima kitab tafsir sebelumnya, tetapi ia merupakan persepsi sebagian orang sebagaimana diungkapkan oleh Zainur Rahman yang dikokohkan oleh sebuah hadis hasan riwayat Ahmad ibn Hanbal (164-241 H.) dalam al-Musnad. Hadis ini menyebutkan secara spesifik bekas hitam di antara dua mata termasuk ciri-ciri Khawarij yang dikecam oleh Nabi. ${ }^{57}$ Sayangnya, hadis ini tidak sekali pun disebut dalam lima kitab tafsir di atas.

Semua mufasir penulis lima kitab tafsir dan para informan di atas cenderung menafsirkan athar al-sujüd dalam QS. al-Fath [48]: 29 dalam penafsiran abstrak, yang bisa dirasakan baik di dunia maupun di akhirat. Di sisi lain, penafsiran konkret atas athar al-sujūd berupa bekas hitam di dahi karena sering sujud cenderung diabaikan karena tiga faktor. Pertama, ia tidak didukung oleh ayat dan hadis sahih. Kedua, bukti minim, karena bukti valid satu-satunya hanya adanya dua orang yang berjidat hitam karena sering sujud, yaitu 'Alī ibn alḤusayn Zayn al-'Âbidīn dan 'Alī ibn 'Abd Allāh ibn 'Abbās Abū al-Amlāk, yang dijuluki dhū al-thafināt. Ketiga, ada hadis yang menunjukkan bahwa Nabi Muhammad saw., Abū Bakr, 'Umar, dan 'Uthmān tidak memiliki bekas hitam di dahi. Bahkan sebagian salaf saleh membencinya, sebagaimana hadis-hadis riwayat al-Bayhaqī dalam al-Sunan al-Kubrä. ${ }^{58}$

56Budi Santoso, “Bahasa dan Identitas Budaya," Sabda 1, no. 1 (2006): 44-9.

${ }^{57}$ Aḥmad ibn Hanbal, al-Musnad, Juz 15 (Kairo: Dār al-Ḥadīth, 1995), 42-3.

58al-Bayhaqī, al-Sunan al-Kubrā, Juz 2: 406-7.

JURNAL THEOLOGIA — Volume 29, Nomor 2, Desember 2018 
Uraian di atas menunjukkan ada kesenjangan antara data dari lima kitab tafsir dan persepsi sebagaian masyarakat tentang athar al-sujūd sebagai identitas sosial-keagamaan. Pada ranah tafsir, penafsiran abstrak atas athar al-sujūd lebih mendapatkan tempat, meskipun tidak semua mufasir menolak penafsiran konkretnya dengan batasan tertentu, yaitu tidak riyā' dan ketidaksengajaan. Pada ranah kehidupan riil, sebagian kelompok umat Islam (pihak pertama) mengindentikkan penafsiran konkret atas athar al-sujūd pada kelompok lain (pihak kedua) sebagai stigma. Padahal referensi kitab tafsir pihak pertama mengafirmasi penafsiran konkret tersebut, sedangkan referensi kitab tafsir pihak kedua menegasikannya.

Dengan demikian, kontroversi jidat hitam ini sebenarnya tidak hanya dipicu oleh kesalahtafsiran atas frasa athar al-sujüd dalam QS. al-Fath [48]: 29, tetapi lebih dipicu oleh pemahaman terhadap pelbagai hadis terkait dengan frasa ini, yang sebagiannya tidak disebutkan sebagai materi pelengkap penafsirannya, terutama hadis riwayat Ahmad, ${ }^{59}$ al-Bayhaqī, ${ }^{60}$ dan al-Bukhārī (194-256 H.). ${ }^{61}$

Tak ayal, perbedaan penafsiran ini memengaruhi kehidupan beragama dan berbangsa umat Islam di Indonesia, terutama di Madura, sehingga peluang terjadinya disintegrasi tetap menganga. Kelapangdadaan dan keterbukaan atas perbedaan penafsiran mutlak diperlukan, karena sejatinya tidak ada satu kelompok pun di antara mereka yang menginginkan kontroversi dari stereotip jidat hitam, baik sebagai subjek penuduh maupun objek tertuduh sebagai kelompok jidat hitam.

\section{F. Kesimpulan}

Dari paparan di atas, beberapa kesimpulan dapat ditarik tentang kontroversi jidat hitam di Madura terkait penafsiran frasa athar al-sujūd dalam QS. al-Fath [48]: 29.

${ }^{59}$ Hanbal, al-Musnad, Juz 15: 42-3.

60al-Bayhaqī, al-Sunan al-Kubrā, Juz 2: 406-7.

${ }^{61} \mathrm{Abū}$ 'Abd Allāh Muhammad ibn Ismā'īl al-Bukhārī, Șaḥịh al-Bukhārī. Beirut: (Beirut: Dār Ibn Kathīr, 2002), 1630-1. 
Pertama, athar al-sujūd dalam QS. al-Fath [48]: 29 ditafsirkan dengan dua model penafsiran, yaitu: 1) penafsiran abstrak, berupa kekhusyukan, ketawadukan, ketundukan, dan wajah yang bersih, bercahaya, jernih, serta bening sebagai efek ibadah, baik yang terlihat di dunia maupun di akhirat kelak; dan 2) penafsiran konkret, berupa bekas hitam di dahi(nuktah)yang menyerupai thafinah al-baitr (bagian tubuh unta yang menempel tanah saat menderum). Penafsiran abstrak ini diafirmasi oleh semua penafsir dari lima aliran berbeda dan semua informan, sedangkan penafsiran konkretnya hanya diafirmasi oleh sebagian penafsir dan informan.

Kedua, stigma sebagai "kelompok jidat hitam" terhadap kelompok tertentu berdasarkan kitab tafsir rujukan mereka terbukti kurang tepat, karena kitab tafsir rujukan kelompok yang selama ini diidentikkan sebagai kelompok ini seperti Taysīr al-Karīm al-Raḥmān karya al-Sa'dī dan Fī Zilāl al-Qur'ān karya Quțub justeru menafikan penafsiran konkret atas athar al-sujūd sebagai bekas hitam di dahi (nuktah). Sebaliknya, kitab tafsir rujukan kelompok yang selama ini tidak tersentuh oleh stigma ini seperti al-Kashshāf karya al-Zamakhshārī, Rūh al-Ma'ānī karya al-Alūsī, dan al-Mīzōn karya al-Ṭabāțabāî̀ justeru mengafirmasi dua model penafsiran tersebut atas athār al-sujūd.

Ketiga, pemicu kontroversi jidat hitam bukan hanya athar al-sujūd dalam QS. al-Fath [48]: 29, tetapi beberapa hadis yang diriwayatkan oleh Ahmad ibn Ḥanbal dalam al-Musnad, al-Bayhaqī dalam al-Sunan al-Kubrā, dan al-Bukhārī dalam al-Jāmi' al-Sahịh yang tidak disebutkan dalam lima kitab tafsir tersebut sebagai materi pelengkap penafsiran dan memang mencela umat Islam yang berjidat hitam sebagai ciri Khawarij dan salah sujud dalam beribadah. Padahal tidak satu pun kelompok dalam Islam yang menginginkannya, baik sebagai subjek penuduh maupun sebagai objek tertuduh sebagai "kelompok jidat hitam".]

\section{DAFTAR PUSTAKA}

al-Așfahānī, al-Rāghib. Mufradāt Alfāạ al-Qur'ān. Damaskus: Dār al-Qalam, 2009.

al-Baghdādī, al-Alūsī. Rūh al-Ma'ānī fi Tafsìr al-Qur'ān al-'Azīim wa al-Sab'alMathānī. Beirut: Dār Ihyā̄' al-Turāth al-'Arabī, n.d. 
al-Bāqī, Muḥammad Fu'ād 'Abd. al-Mu'jam al-Mufahras li Alfāz al-Qur'ān al-Karīm. Kairo: Dār al-Ḥadìth, 1364.

al-Bayhaqī, Abū Bakr Aḥmad ibn al-Ḥusayn ibn 'Alī. al-Sunan al-Kubrā. Beirut: Dār al-Kutub al-'Ilmìyah, 2003.

al-Bukhārī, Abū 'Abd Allāh Muhammad ibn Ismāîl. Șahịḥ al-Bukhārī. Beirut: Beirut: Dār Ibn Kathīr, 2002.

al-Dhahabī, Muhammad Ḥusayn. al-Tafsìr wa al-Mufassirūn. Kairo: Maktabah Wahbah, 2000.

Hanbal, Ahmad ibn. al-Musnad. Vol. 15. Kairo: Dār al-Ḥadīth, 1995.

Hasan, Akhmad Muawal. "Sayyid Qutb Mati, Tapi Idenya Abadi bagi Kaum IslamPolitik." Tirto.id - Humaniora, 2017. https://tirto.id/sayyid-qutb-mati-tapiidenya-abadi-bagi-kaum-islam-politik-cvvc.

Hasan, Noorhaidi. “Multikulturalisme dan Tantangan Radikalisme." In Merayakan Kebebasan Beragama: Bunga Rampai 70 Tahun Djohan Effendi, diedit oleh Elza Peldi Taher. Jakarta: ICRP, 2009.

https://tirto.id/dahi-hitam-freddy-budiman-bx5a

https://www.youtube.com/results?search_query=hitam+di+jidat,

https://www.youtube.com/results?search_query=dahi+hitam,

https://www.youtube.com/results?search_query=bekas+hitam+di+dahi, dan

https://www.youtube.com/results?search_query=atsar+al-sujud

Jamal, Khairunnas. "Pengaruh Pemikiran Husain Thabathaba'i dalam Tafsir Al Mishbah." Jurnal Ushuluddin 17, no. 2 (2011): 202-13. https://doi.org/ 10.24014/JUSH.V17I2.692.

Manzūū, Ibn. Lisān al-'Arab. Beirut: Dār al-Fikr, 1386.

Mawardi, Mawardi. "Subjektivitas dalam Penafsiran al-Quran: Fenomena Tafsir Bercorak Sektarian." At-Tibyan: Jurnal Ilmu Al-Qur'an dan Tafsir 3, no. 1 (2018): 125-38. https://doi.org/10.32505/tibyan.v3i1.483.

Mudzakkir, Amin. "Demokratisasi, Islamisasi, dan Posisi Kaum Minoritas: Pengalaman Indonesia (1)." Politik LIPI, 2012. http://www.politik. lipi.go.id/kolom/kolom-1/politik-internasional/680-demokratisasiislamisasi-dan-posisi-kaum-minoritas-pengalaman-indonesia-1. 
al-Miṣrī, Abū al-Ashbāl Aḥmad ibn Sālim. Shadharāt al-Balāțīn min Siyar al-Ulamā' al-Mu'āșisiñn. Riyaḍ: Dār al-Kayān, 2006.

Mustaqim, Abdul. Paradigma Tafsir Feminis: Membaca al-Qur'an dengan Optik Perempuan. Yogyakarta: Logung Pustaka, 2008.

al-Naysābūrī, Abū 'Abd al-Raḥmān Ismāîl ibn Aḥmad al-Ḥayrī. Wujūh al-Qur'ān. Masyhad: Majma' al-Buhūth al-Islāmīyah, 1422.

Quțub, Sayyid. Fī Ẓilāl al-Qur'ān. Kairo: Dār al-Shurūq, 2003.

Rohman, Izza. "Salafi Tafsirs: Textualist and Authoritarian?" Journal of Qur'an and Hadith Studies 1, no. 2 (2012): 197-213. https://doi.org/10.1548/ QUHAS.V112.1324.

al-Sa'dī, Abd al-Raḥmān ibn Nāṣir. Taysīr al-Karīm al-Raḥmān fi Tafsīr Kalām alMannān. Riyāḍ: Dār al-Salām, 2002.

Santoso, Budi. “Bahasa dan Identitas Budaya." Sabda 1, no. 1 (2006): 44-49.

Sirry, Mun'im. "Berlomba-lombalah dalam Kebaikan: Tafsir 5:48 dan Diskursus Kontemporer Pluralisme Agama." Dalam Merayakan Kebebasan Beragama: Bunga Rampai 70 Tahun Djohan Effendi, ed. Elza Peldi Taher. Jakarta: ICRP, 2009.

al-Ṭabāțabāîn, al-Sayyid Muḥammad Ḥusayn. al-Mīzān fi Tafsìr al-Qurāān. Beirut: Mu’assasah al-A'lamī li al-Mațbūāt, 1997.

Thaha, Idris. "Hubungan Islam dan Politik yang Mungkin di Indonesia." Studia Islamika 13, no. 2 (2006): 327-46. https://doi.org/10.15408/ sdi.v13i2.572.

Tim Redaksi Pusat Bahasa. Kamus Besar Bahasa Indonesia. Jakarta: Gramedia Pustaka Utama, 2013.

Wahid, Abdurrahman, ed. Ilusi Negara Islam: Ekspansi Gerakan Islam Transnasional di Indonesia. Jakarta: LibForAll Foundation, 2009.

Zakarīyā, Abū al-Ḥusayn Ahmad ibn Fāris ibn. Mu'jam Maqāȳ̄s al-Lughghah. 1 ed. Beirut: Dār al-Fikr, 1979.

al-Zamakhsharī, Jār Allāh Abū al-Qāsim Maḥmūd ibn 'Umar. al-Kashshāf 'an Haqā'iq Ghawāmị̣ al-Tanzīl wa 'Uyūn al-Aqāwīl fi Wujūh al-Ta'wīl. Riyāḍ: Maktabah al-'Ubaykān, 1998. 
Zamzami, M. Subhan. "Tafsir Ideologis dalam Khazanah Intelektual Islam." Mutawātir: Jurnal Keilmuan Tafsir Hadis 4, no. 1 (2014): 163-77. https://doi.org/10.15642/mutawatir.2014.4.1.163-177.

Zaprulkhan, Zaprulkhan. "Relasi Agama dan Negara dalam Perspektif Islam." Walisongo: Jurnal Penelitian Sosial Keagamaan 22, no. 1 (2014): 105-32. https://doi.org/10.21580/WS.22.1.261.

Zuhdi, Muhammad Harfin. "Fundamentalisme dan Upaya Deradikalisasi Pemahaman al-Qur'an dan Hadis." Religia 13, no. 1 (2010): 81-101. https://doi.org/10.28918/religia.v13i1.176. 